\title{
Penggunaan Media Pembelajaran Daring Pada Siswa Kelas 3 SD Negeri 5 Blahbatuh di Masa Pandemi COVID-19
}

\author{
I Wayan Subaker ${ }^{1}$, Nyoman Suryawan ${ }^{2}$, Diah Nirmala Dewi ${ }^{3}$, Ni Wayan Yusi Armini ${ }^{4}$ \\ ${ }^{12}$ IKIP Saraswati Tabanan \\ ${ }^{34}$ Universitas Hindu Negeri I Gusti Bagus Sugriwa Denpasar \\ ${ }^{1}$ wayan.subaker@gmail.com, ${ }^{2}$ nymsuryawan3@gmail.com, ${ }^{3}$ nlu39they@yahoo.com, \\ 4yusiarmini14@gmail.com
}

\begin{abstract}
The COVID-19 pandemic has changed everyone's life in all aspects of life. The government has limited all community activities so that there are no crowds to avoid and break the chain of the spread of COVID-19. Based on the contents of circular letter number 15 of 2020 regarding Guidelines for Organizing Learning from Home in an emergency period of the spread of Covid-19, the Education Office of Gianyar Regency has shifted teaching and learning activities in the classroom to online or virtual learning. This phenomenon is certainly a new thing experienced by an educator and also experienced by students because they have to use online learning media as a liaison between teachers and students. The use of online learning media during the COVID-19 pandemic is an alternative choice to provide a sense of security in teaching and learning. At SD N 5 Bahbatuh, especially in grade III, the policy of the learning media used is WhatsApp. Seeing the ability of students who can only apply cellphones to WhatsApp media. Based on the results of this study, researchers can conclude that the use of learning media that is often used by teachers and preferred by students, namely WhatsApp Group is because it is easy to access and does not require a lot of quota to access it. However, as for the obstacles that students often experience when learning online during the pandemic, it is difficult to understand the subject matter, not to mention the tasks given by teachers and also parents who have busy schedules cannot always guide their children in online learning. Therefore, this online learning makes students unhappy.
\end{abstract}

Keywords: Online Learning; Learning Media; Third Grade Students

\begin{abstract}
Abstrak
Pandemi Covid-19 merubah semua tatanan hidup semua orang didalam segala aspek kehidupan. Pemerintah membatasi seluruh aktivitas masyarakat supaya tidak adanya kerumunan untuk menghindari dan memutus rantai penyebaran Covid-19. Berdasarkan isi surat edaran nomor 15 tahun 2020 tentang Pedoman Penyelenggaraan Belajar dari Rumah dalam masa darurat penyebaran Covid-19, Dinas Pendidikan Kab.Gianyar mengalihkan kegiatan belajar mengajar di kelas menjadi belajar daring atau virtual. Fenomena ini tentunya merupakan hal baru yang dialami seorang pendidik dan juga dialami oleh peserta didik karena harus menggunakan media pembelajaran daring sebagai penghubung antara guru dengan siswa. Penggunaan media pembelajaran daring selama masa pandemi Covid19 menjadi alternatif pilihan untuk memberikan rasa aman dalam belajar mengajar. Di SD Negeri 5 Bahbatuh khususnya di kelas III, kebijakan dari media pembelajaran yang dipergunakan ialah WhatsApp. Melihat kemampuan siswa yang hanya bisa mengaplikasikan handphone pada media whatsapp saja. Berdasarkan hasil penelitian ini, peneliti dapat menyimpulkan bahwa penggunaan media pembelajaran yang sering digunakan guru dan disukai oleh siswa yaitu WhatsApp Group ini dikarenakan mudah
\end{abstract}


untuk diakses dan tidak membutuhkan banyak kuota untuk mengaksesnya. Namun adapun kendala yang sering dialami siswa saat pembelajaran daring dimasa pandemi yaitu sulit memahami materi pelajaran, belum lagi tugas yang diberikan guru dan juga orangtua yang memiliki kesibukan tidak bisa selalu membimbing anak-anaknya dalam belajar daring. Oleh karena itu pembelajaran daring ini membuat siswa tidak senang.

Kata Kunci : Belajar Daring; Media Pembelajaran; Siswa kelas III

\section{Pendahuluan}

Dunia pendidikan sangat penting untuk diteliti karena selalu menemukan hal-hal yang unik serta menarik untuk diulas. Seperti halnya pendidikan pada masa pandemi Covid-19 seperti saat sekarang yang memberikan tantangan baru bagi dunia pendidikan terutama pada anak Sekolah Dasar (SD). Kita ketahui bahwa virus Covid-19 melanda Indonesia sudah lebih dari satu tahun. Sejak diumumkan kasus pertama pada 2 Maret 2020 hingga saat ini 2 Oktober 2021 sudah sangat banyak terkonfirmasi positif. Virus Covid-19 ini sangat mematikan dengan penyebaran yang begitu cepat melalui kontak fisik. Mencegah penyebaran virus Covid-19 ini Pemerintah Kab. Gianyar memberlakukan pembatasan aktivitas masyarakat hampir disemua sektor kehidupan masyarakat. Tentunya ini berdampak terhadap banyak sektor mulai dari sosial, ekonomi bahkan pendidikan. Pelaksanaan pendidikan pada masa pandemi sekarang ini juga terpengaruh. Sektor pendidikan sendiri melalui SE Mendikbud Nomor 4 tahun 2020 tentang pelaksanaan kebijakan pendidikan dalam masa darurat Corona Virus Disease (COVID-19) (Menteri Pendidikan dan Kebudayaan, 2020). Dari SE tersebut mengharuskan siswa, guru, kepala sekolah serta warga sekolah lainnya melakukan kegiatan belajar mengajar dan administrasi secara daring dari rumah. Pelaksanaan pembelajarn daring jelas berbeda dengan pembelajaran tatapmuka secara langsung yang terjadi di kelas, karena pembelajaran daring memisahkan ruang antara siswa dan guru.

Pembelajaran daring merupakan pembelajaran yang dilakukan dengan pemanfaatan koneksi jaringan internet untuk mengakses dan juga menyalurkan materi belajar. Pembelajaran daring lebih fleksibel dari segi ruang dan waktu karena dapat diakses dimanapun dan kapanpun asalkan jaringan internet tersedia dengan baik. Pembelajaran agar dapat berjalan dengan baik dan lancar, tentunya memerlukan media pembelajaran yang tepat untuk menghubungkan keduanya secara bersamaan. Media pembelajaran adalah semua bentuk alat komunikasi yang bersifat menyalurkan pesan dari sumber pesan kepada siswa sehingga dapat merangsang pikiran, minat, perasaan dan kemauan siswa dalam melakukan proses pembelajaran (Asmariani, 2016).

Penggunaan media pembelajaran memiliki peran penting saat ini, karena dapat membangkitkan minat dan motivasi belajar siswa kelas III SD Negeri 5 Blahbatuh jika menggunakan dengan benar dan memilih media yang tepat, sehingga dapat tercapainya tujuan pembelajaran secara efektif dan efisien. Dengan perkembangan teknologi yang semakin canggih, banyak media pembelajaran daring yang bisa menunjang pembelajaran jarak jauh seperti sekarang. Media pembelajaran menunjang pembelajaran daring, tentu pemerintah tidak memandang sebelah mata dalam memberikan dukungan dalam dunia pendidikan. Berdasarkan arahan dari Bapak Presiden, Kemendikbud terus mengembangkan dukungan melalui kerjasama dengan beberapa mitra swasta untuk memberikan layanan media pembelajaran secara gratis untuk dapat diakses oleh pendidik dan peserta didik. Berbagai jenis media pembelajaran tentunya tidak semua bisa digunakan oleh guru dan siswa. Oleh karena itu guru harus memilih media 
yang cocok dan sesuai dengan situasi dan kondisi siswa kelas III di SD Negeri 5 Blahbatuh. Penggunaan media pembelajaran tentunya akan berdampak pada pemahaman siswa didalam menerima dan memahami materi ajar yang disampaikan oleh guru bidang study. Dengan menentukan penggunaan media pembelajaran yang tetap dan tepat, tentunya kegiatan belajar mengajar akan berjalan dengan efektif dan efisien.

\section{Metode}

Penelitian yang berjudul Penggunaan Media Pembelajaran Daring pada Siswa Kelas III SD Negeri 5 Blahbatuh di masa Pandemi Covid-19 ini menggunakan metode pendekatan kualitatif, suatu proses penelitian menemukan pengetahuan dengan observasi dan wawancara sebagai alat untuk menemukan keterangan mengenai apa yang ingin penulis ketahui, bertujuan untuk menjelaskan atau mendeskripsikan fenomena-fenomena dari hasil temuan di lapangan sesuai dengan fokus permasalahan yang diteliti dan berdasarkan fakta yang ada di lapangan.

\section{Hasil dan Pembahasan}

\section{Media Pembelajaran Daring}

Media pembelajaran daring dapat diartikan sebagai media yang dilengkapi dengan alat pengontrol yang dapat dioperasikan oleh pengguna (user), sehingga pengguna (user) dapat mengendalikan dan mengakses apa yang menjadi kebutuhan pengguna, misalnya mengunduh sumber-sumber untuk materi bahan ajar pada pelajaran Agama Hindu. Keuntungan penggunaan media pembelajaran daring yaitu selain pembelajaran yang sifatnya mandiri dan interaktiv siswa juga mampu meningkatkan tingkat ingatan, mampu memberikan lebih banyak pengalaman belajar, dengan teks, dengan audio, video dan bisa juga dengan animasi yang semuanya digunakan untuk menyampaikan materi bahan ajar, dan juga memberikan kemudahan dalam menyampaikan, mengunduh, siswa juga bisa mengirim pesan kepada siswa lain, mengirim komentar pada forum diskusi, memakai ruang chat, hingga panggilan video untuk berkomunikasi langsung.

Pembelajaran yang semula dilaksanakan secara luring (tatap muka) sekarang dilakukan secara daring menggunakan media pembelajaran online. Media online yang digunakan sebagai pendukung untuk pembelajaran daring siswa kelas III SD Negeri 5 Blahbatuh yaitu whatsapp group. Dalam pelaksanaannya guru lebih memilih menggunakan whatsapp sebagai media pembelajaran karena lebih efektif untuk siswa terutama ditingkat Sekolah Dasar (SD). Whatsapp sendiri merupakan media online yang banyak digunakan oleh mahasiswa, guru, dan dosen. Penggunaan whatsapp sebagai media pembelajaran mampu memberikan kemudahan didalam berinteraksi dan berkomusikasi, serta tidak terbatas akan waktu. Inilah yang menyebabkan whatsapp banyak dijadikan sebagai media pembelajaran untuk ana-anak ditingkat Sekolah Dasar (SD). Fitur whatsapp yang sering digunakan oleh guru di SD Negeri 5 Blahbatuh sebagai media pembelajaran yaitu obrolan group whatsapp.

Dalam pelaksanaannya di tingkat Sekolah Dasar terutama pada siswa kelas III SD Negeri 5 Blahbatuh, seperti biasa seorang guru memberikan tugas sesuai dengan jadwal mata pelajaran pada hari itu baik bentuk tugas secara lisan, tulisan maupun praktek, yang berikutnya setelah disimak dan dicermati harus dikerjakan oleh siswa dan dilakukan oleh siswa. Kemudian hasil yang sudah dari tugas yang dikerjakan tersebut dikirimkan kembali kedalam group whatsapp baik itu berupa gambar/foto maupun berupa video. Pada saat tugas yang dikerjakan berupa gambar/foto, siswa mampu mengerjakan sendiri akan tetapi ketika tugas yang diberikan oleh guru adalah membuat video karena mata pelajaran saat itu adalah praktek maka disini memelukan bantuan orangtua siswa untuk mengarahkan atau membantu memegang handphone supaya video yang dihasilkan oleh siswa 
terselesaikan dengan hasil yang baik. Data atau presensi kehadiran pun dilakukan menggugunakan link yang dikirimkan di whatsapp group.

Whatsapp group salah satu fitur yang terdapat didalam aplikasi Whatsapp. Whatsapp merupakan media yang saling bertukar pesan melalui smartphone yang bisa dikoneksikan ke laptop melalui whatsappweb tentunya dengan koneksi internet. Media ini diciptakan oleh Ian Koum pada tahun 2009 dan sekarang sudah digunakan di 180 negara dengan jumlah pengguna lebih dari 2 miliar orang yang tersebar di seluruh dunia (WhatsApp LLC, 2021). Media whatsapp ini mempermudah kita untuk bertukar pesan kepada keluarga, teman, kerabat, dimanapun dan kapanpun yang terpenting handphone terhubung dengan jaringan internet. Bertukar pesan melalui whatsapp bisa melalui teks, foto, audio, video, dokumen, lokasi, melakukan panggilan suara dan panggilan video. Pemanfaatan whatsapp dalam proses pembelajaran daring pada masa pandemi sangat membantu seperti sekarang dengan menggunakan whatsapp group oleh guru. Whatsapp group bisa menjadi alternatif media pembelajaran daring yang digunakan oleh guru di SD Negeri 5 Blahbatuh untuk siswa kelas III pada masa pandemi dengan memanfaatkan fitur whatsapp group sebagai ruang belajar daring untuk memberikan dan menjelaskan materi pembelajaran baik itu secara teori mauapun praktek bahkan diskusi kelas. Semuanya bisa dilakukan dengan whatsapp group seperti yang terlihat pada gambar berikut.

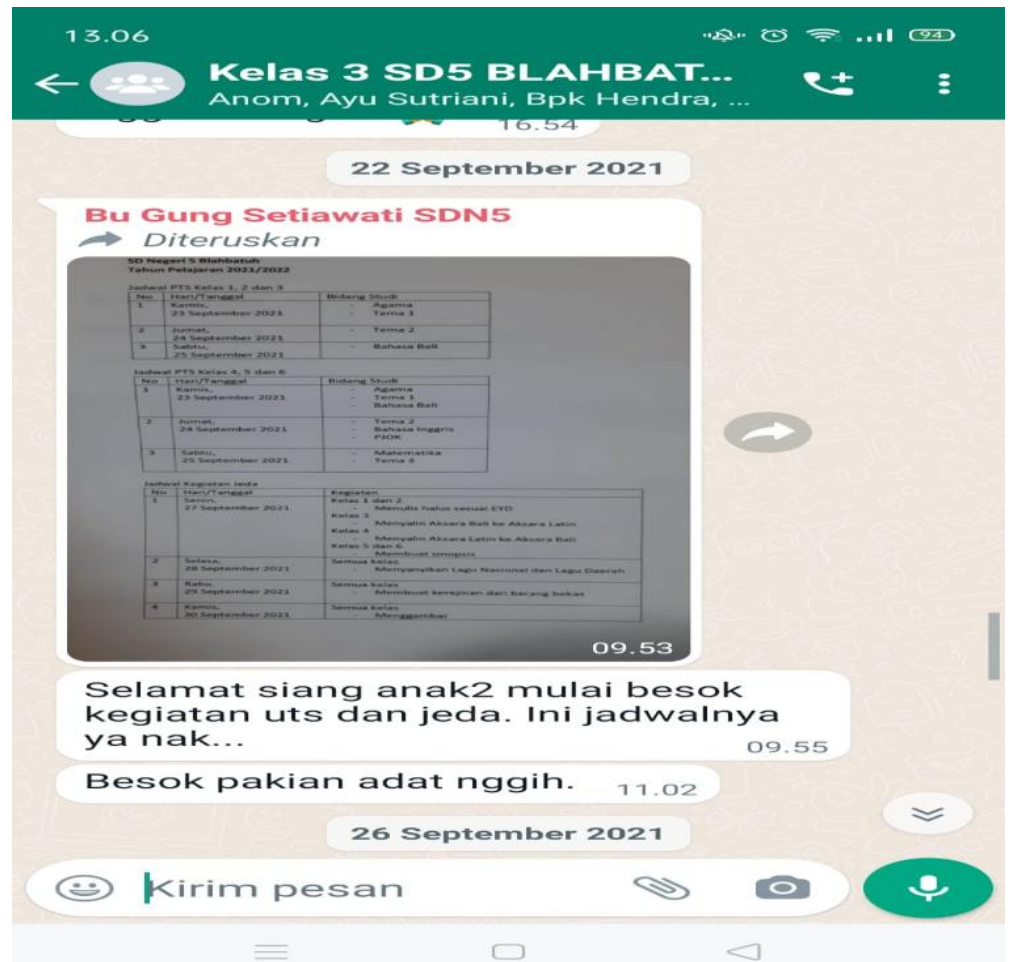

\section{Gambar 1. Photo Whatsapp Group Siswa Kelas III SD Negeri 5 Blahbatuh Dokumentasi : Diah}

Penggunaan whatsapp group sebagai media pembelajaran siswa kelas III di SD Negeri 5 Blahbatuh memudahkan siswa berinteraksi dengan guru selama proses belajarmengajar, selain itu dengan menggunakan media whatsapp juga menghemat biaya kuota internet yang dipergunakan dalam rumah tangga. Media pembelajaran whatsapp juga memiliki sisi negatif yang terfokus kepada pengerjaan tugas siswa, kurang dalam bersosial, siswa dalam pengerjaan tugasnya terkadang dilakukan di sore hari (karena tidak terbatas waktu), sulit bagi seorang guru untuk mengukur tingkat pemahaman siswa terhadap materi yang diberikan atau dishare di whatsapp group. Dengan demikian bahwa 
whatsapp bisa saja dipandang kurang efektif untuk dijadikan sebagai media pembelajaran. Akan tetapi didalam penggunaan whatsapp group sebaiknya guru lebih mengoptimalkan penggunaan media agar lebih sistematis, edukatif, dan interaktif. Hal ini dapat dilakukan dengan membuat video kreatif maupun audio pembelajaran yang menarik bagi siswa terutara siswa kelas III. Terkait bagaimana strategi dan teknik pembuatan video kreatif, seorang guru bisa saling berdiskusi melalui surat elektronik.

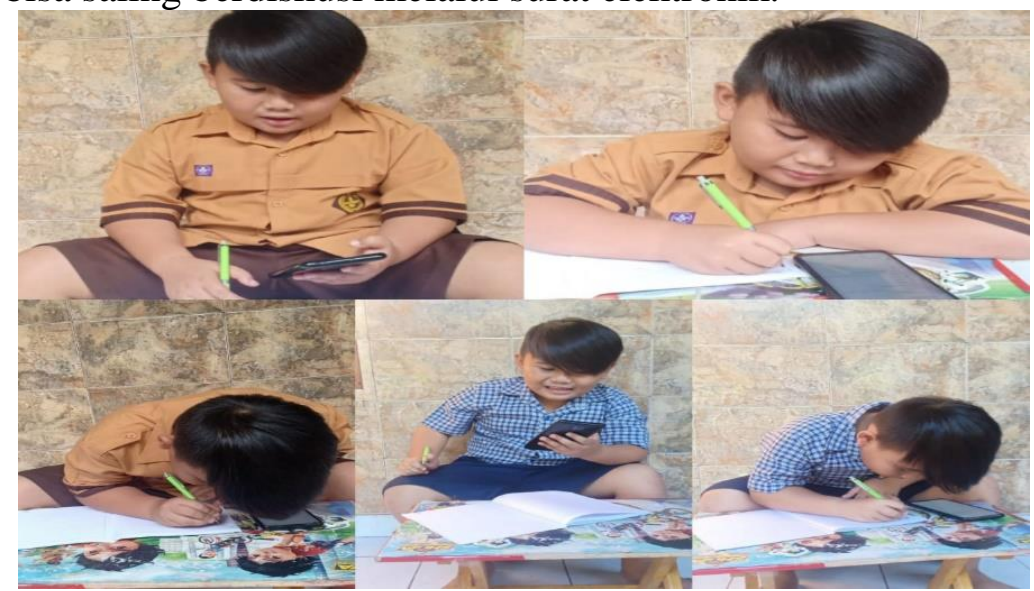

Gambar 2. Photo Salah Satu Siswa Kelas III SD Negeri 5 Blahbatuh Melakukan

Pembelajaran daring melalui media pembelajaran whatsapp group.

Dokumentasi : Diah

\section{Pembelajaran Pada Masa Covid-19}

Sebelum penulis menguraikan tentang pembelajaran pada masa Covid-19, terlebih dulu akan diuraikan tentang pembelajaran. Pembelajaran berasal dari kata "belajar" yang mendapat prefiks "pe-". Prefiks tersebut dalam proses nasalisasi berubah menjadi pe-, pen, dan pem,. Selain itu mendapat Sufiks "-an" yang berfungsi untuk membentuk kata benda. Jadi kata " belajar " bila mendapat prefiks pe- dan sufiks -an akan berubah bentuk menjadi "pembelajaran". Menurut Kamus Besar Bahasa Indonesia bahwa arti kata "pembelajaran" adalah proses, cara, perbuatan menjadikan orang atau makhluk hidup belajar. Pembelajaran adalah suatu proses interaksi peserta didik dengan pendidik dan sumber belajar pada suatu lingkungan belajar. Dengan kata lain, bahwa pembelajaran adalah proses untuk membantu peserta didik agar dapat belajar dengan baik. Pemerintah Kab. Gianyar mengambil kebijakan bahwa seluruh sekolah yang berada di kab. Gianyar wajib melakukan proses kegiatan belajar-mengajar secara daring. Kebijakan ini diambil pemerintah dengan upaya pencegahan dan menekan penyebaran semakin bertambahnya kasus positif Covid-19 yang sangat meresahkan masyarakat. Dengan kebijakan seperti ini SD Negeri 5 Blahbatuh juga melaksanakan kegiatan belajar-mengajar secara daring.

Kebijakan pemerintah tentunya ketidakmerataan kualitas pendidikan Indonesia menjadi kendala utama penerapan kebijakan sekolah daring ini, karena kesiapan peserta didik yang bersekolah di perkotaan sangat berbeda dengan peserta didik yang bersekolah di daerah pelosok maupun yang berasal latar belakang ekonomi sang peserta didik. Teknologi merupakan hal yang terpenting dalam pembelajaran daring, teknologi tersebut diantaranya bisa berupa smartphone, laptop dan benda pendukung lainnya. Smartphone merupakan hal yang paling umum digunakan oleh peserta didik daripada laptop, karena lebih praktis dan banyak fitur canggihnya (Subiyakto,B.,Susanto,H.,\&Akmal,H.,019).

Pembelajaran daring yang diselenggarakan oleh guru dan siswa dengan menggunakan beberapa platform digital yang menarik dan membantu untuk meningkatkan keefektifan belajar siswa selama masa pandemi ini. Beberapa platform 
digital tersebut diantaranya Google Class Room, E-Learning, Edmodo, Zoom dan Google Meet. Sekolah-sekolah di Kab. Gianyar juga telah mengimplementasikan pembelajaran daring karena selain untuk mengurangi penyebaran virus, pembelajaran harus tetap terlaksanakan agar peserta didik tetap dapat memperoleh materi pelajaran pada masa pandemi. Para guru tentunya dapat menggunakan aplikasi-aplikasi untuk menunjang proses pembelajaran daring atau jarak jauh. Ditingkat Sekolah Dasar (SD) para guru memilihi menggunakan media whatsapp. Pengunaan whatsapp pada siswa kelas III SD Negeri 5 Blahbatuh sangat membantu komukasi dan berinteraksi antara guru dengan siswa dalam proses pembelajaran berlangsung. Penggunaan whatsapp merupakan sebagai sumber informasi, sumber belajar, sistem dan kualitas layanan yang telah memberikan dampak pada proses pembelajaran pada masa Covid-19 ini yang sebagian besarnya bermanfaat pada proses pembelajaran daring ditingkat anak-anak sekolah dasar khususnya kelas III di SD Negeri 5 Blahbatuh.

\section{Dampak Pembelajan Daring terhadap siswa kelas III SD Negeri 5 Blahbatuh}

Di tengah wabah Covid-19 sekarang ini, dengan menerapkan pembelajaran Daring bermanfaat untuk melindungi peserta didik dari penyebaran virus Covid-19. Apalagi pemerintah sudah menghimbau agar masyarakat atau siswa dapat beraktivitas di rumah sebagai upaya untuk menjaga jarak fisik demi untuk menekan bertambanya jumlah penyebaran virus. Dalam proses pelaksanaan pendidikan dengan menggunakan model pembelajaran daring yang dilakukan pada masa covid-19 ini, tentunya terdapat dampak diantaranya kelebihan dan kekurangan yang sangat spesifik yang perlu mendapat perhatian dari masyarakat.

a. Kelebihan proses pelaksanaan pendidikan yang dilakukan dengan menggunakan mode

Daring tersebut antara lain adalah :

1) Pembelajaran dapat diakses dengan mudah oleh siswa dari rumah.

2) Pengeluaran biaya sekolah yang lebih terjangkau.

3) Memiliki waktu belajar sangat fleksibel.

4) Pembelajaran model daring dapat memberikan wawasan yang luas.

b. Selain dampak kelebihan dalam pembelajaran pada masa Covid-19 ini, juga terdapat beberapa kekurangan-kerurangan antara lain adalah:

1) Keterbatasan dalam mengakses internet.

2) Kurangnya interaksi siswa dengan guru.

3) Kurangnya pemahaman siswa terhadap materi pelajaran.

4) Kurangnya pengawasan terhadap siswa dalam belajar. Kurangnya pengawasan terhadap siswa dalam melakukan pembelajaran daring dapat membuat siswa kadang-kadang kehilangan konsentrasi dalam belajar.

\section{Kesimpulan}

Penelitian ini bertujuan mendiskripsikan Penggunaan Media Pembelajaran Daring pada siswa kelas III SD Negeri 5 Blahbatuh di masa Pandemi Covid-19. Hasil penelitian menunjukkan bahwa penggunaan aplikasi pembelajaran daring di SD Negeri 5 Blahbatuh menggunakan aplikasi whatsapp group sebagai sarana penunjang pembelajaran daring. Adapun saran penulis dalam implementasi pembelajaran daring pada masa pandemi Covid-19 ini supaya pembelajaran berjalan lebih efektif, efisien dan menimbulkan semangat siswa-siswa di SD Negeri 5 Blahbatuh khususnya di kelas III untuk terus belajar meskipun pembelajaran daring lebih banyak mengunakan aplikasi Whatsapps group, sebaiknya para guru menyelingkan penggunakan pembelajaran Daring lainnya yang sifatnya dapat menumbuhkan kedekatan antar siswa dan guru, siswa dan siswa dengan mengunakan aplikasi videocall dalam fitur whatsapp tersebut. 
Dalam pemberian materi dan tugas sebaiknya guru mengurangi mengirim materi dan tugas dalam bentuk vidio untuk menghemat penggunaan kuota internet mengingat tidak semua siswa selalu memiliki kuota internet dan mendapatkan bantuan kuota belajar gratis dari pemerintah kab.Gianyar. Dalam pemberian tugas sebaiknya sesuai dengan jadwal mata pelajaran yang ada dengan pemberian soal dan penugasan sebaiknya bervariatif agar tidak menimbulkan kejenuhan pada siswa, dan siswa menjadi tertantang untuk menyelesaikan tugas yang diberikan oleh gurunya. Guru sebaiknya memberikan toleransi waktu kepada siswa dalam mengumpulkan dan menyelesaikan tugas mengingat tidak semua siswa kelas III di SD Negeri 5 Blahbatuh memiliki handphone sendiri, dan sebaiknya tetap memberikan materi terlebih dahulu sebelum memberikan soal penugasan yang harus diselesaikan oleh siswa.

Dalam pembelajaran daring, sebaiknya guru menggunakan aplikasi pembelajaran daring yang bervariasi, dengan cara menggabungkan dua pembelajaran daring pada pemberian materi dan tugas pembelajaran misalnya menggunakan aplikasi Whatsapp kemudian sesekali waktu diselingi penggunaan aplikasi Zoom. Hal ini dilakukan supaya pembelajaran daring tidak terasa membosankan dan memunculkan minat dan motivasi siswa untuk terus belajar dan membuat anak-anak merasa senang dengan melihat seluruh teman-teman satu angkatan dalam satu layar.

\section{Daftar Pustaka}

Adit,A.(2020).12 Aplikasi Pembelajaran Daring Kerjasama Kemendikbud, Kompas.Com. https://edukasi.kompas.com/read/2020/03/22/123204571/12aplikasi-pembelajaran-daring-kerjasama-kemendikbud-gratis?page=all

Asmariani, A. (2016). KONSEP MEDIA PEMBELAJARAN PAUD. Al-Afkar : Jurnal Keislaman \& Peradaban. https://doi.org/10.28944/afkar.v5i1.108

Siti Aisyahet al Penggunaan Media Pembelajaran Daring .Jurnal Riset Madrasah Ibtidaiyah(JURMIA). Vol. 1, No.1\|56 Pendidikan Universitas Pendidikan Ganesha Singaraja,

March. https://www.researchgate.net/publication/315105651

Kemendikbud Terus Galang Dukungan Pengembang Pembelajaran Daring. Www.Kemdikbud.Go.Id. Retrieved May 25, 2021, from https://www.kemdikbud.go.id/main/blog/2020/03/laksanakan-arahan-presidenkemendikbud-terus-galang-dukungan-pengembang-pembelajaran-daring 